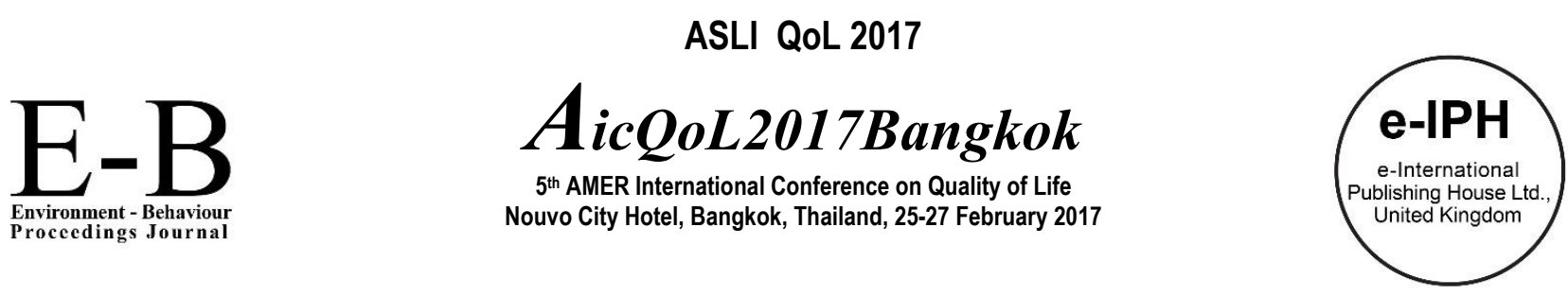

\title{
The Impact of Redevelopment towards Physical and Socioeconomy of Orang Asli in Ulu Kuang Village, Rawang
}

\author{
Jamalunlaili Abdullah*, Muhammad Azri Alwi, Che Bon Ahmad \\ Faculty of Architecture, Planning and Surveying, Universiti Teknologi Mara (UiTM), 40450 Shah Alam, Selangor, Malaysia
}

\begin{abstract}
This study was conducted at Orang Asli settlement in Ulu Kuang Village, Rawang in order to evaluate the impacts of the redevelopment of the settlement towards its physical and socio-economic conditions. 73 out of 92 households were interviewed during the study period. Descriptive, comparative analysis and socioeconomic analyses were conducted. It was found that generally the Orang Asli were satisfied with their physical and socio-economic conditions after the redevelopment, although a few problems remain. Some improvements such as the provision of water tank and waste disposal collecting service, as well as income generation and human development programmes are offered.
\end{abstract}

Keywords: Redevelopment; Orang Asli (aborigines); Socio-economic impacts; physical impacts

ISSN: 2398-4287@ 2017. The Authors. Published for AMER ABRA by e-International Publishing House, Ltd., UK. This is an open access article under the CC BYNC-ND license (http://creativecommons.org/licenses/by-nc-nd/4.0/). Peer-review under responsibility of AMER (Association of Malaysian Environment-Behaviour Researchers), ABRA (Association of Behavioural Researchers on Asians) and cE-Bs (Centre for Environment-Behaviour Studies), Faculty of Architecture, Planning \& Surveying, Universiti Teknologi MARA, Malaysia.

\subsection{Introduction}

The Orang Asli, literally means "original people," are the indigenous minority of Peninsular Malaysia. The Orang Asli are the descendants of the earliest inhabitants of the peninsular. It has been suggested that they retained much of their identity to the present day because of their relative isolation from the other communities and the forces of change (Suki Mee, 2009). The Orang Asli is a community which is rich in knowledge and wisdom about management of the natural environment. Their uniqueness stems from the application of traditional knowledge and wisdom that they inherited from their ancestors. Due to their shy nature and their almost dependence on agriculture and forests produce, they tend to be living within or adjacent to Malaysian tropical rainforest, away from major human settlements.

Due to their remote locations, the Orang Asli tend to lag behind other ethnic groups in Peninsular Malaysia in terms of physical and socio-economic development. While Malaysia is considered to an upper middle-income nation, most of Orang Asli are classified as extremely poor. Their settlements tend to consist of basic wooden houses which are of substandard quality compared to average Malaysian houses. In addition, they lack access to quality healthcare, education and basic amenities which most Malaysian take for granted.

Due to this, the Malaysian government has embarked on various programs to improve the livelihood of the Orang Asli and perhaps to try to assimilate them into the mainstream society of Malaysia. The resettlement of Orang Asli in a new location (ex-situ development) and the redevelopment of Orang Asli settlements are the two main strategies related to the improvement programs for Orang Asli. The main aim of these programs is to provide better government services especially health and education, to the Orang Asli and to improve their socio-economic conditions.

This paper analyses one such program; specifically the redevelopment of Orang Asli settlement in Ulu Kuang, Selangor, Malaysia. It is an in-situ development of existing Orang Asli settlement which is located close to a main urban settlement. It aims to evaluate the redevelopment scheme and its impacts towards the Orang Asli community. Specifically, its objectives are to analyze the redevelopment program and evaluate the physical and socio-economic conditions of the Orang Asli before and after the

\footnotetext{
${ }^{*}$ Corresponding author. Tel.:
}

E-mail address: jamal858@salam.uitm.edu.my

ISSN: 2398-4287C 2017. The Authors. Published for AMER ABRA by e-International Publishing House, Ltd., UK. This is an open access article under the CC BYNC-ND license (http://creativecommons.org/licenses/by-nc-nd/4.0/). Peer-review under responsibility of AMER (Association of Malaysian Environment-Behaviour Researchers), ABRA (Association of Behavioural Researchers on Asians) and cE-Bs (Centre for Environment-Behaviour Studies), Faculty of Architecture, Planning \& Surveying, Universiti Teknologi MARA, Malaysia. 
implementation of the said program. In the end, the paper would present overall impact evaluations and propose strategies to improve the new settlement, should problems are found.

\subsection{Literature Review}

Orang Asli is a minority group that lives in Peninsular Malaysia with a population of 178,197 people in 2011 (Department of Orang Asli Development - JAKOA, 2011). The population size is about $0.5 \%$ of the total population in Malaysia. Historical facts indicate that population in Malaysia began 25,000 years ago and the Orang Asli was the first community that settled in Peninsular Malaysia (Nicholas, 2000). The first group is believed to be from Indo-China and settled in the northern region, while the second group came from the Nusantara Island and settled in the southern part of Peninsular Malaysia. Orang Asli consists of three main races, which are Negrito, Senoi, and Malay-Proto. From these groups, there are seventeen ethnic Orang Asli groups (Suki Mee, 2009).

In Peninsular Malaysia, the main occupations of Orang Asli who live in coastal areas such as Orang Laut, Seletar, and Mahmeri are a fisherman, while Temuan, Jakun, and Semai practice permanent agriculture and even manage their own rubber, oil palm, and other cultivations. The other tribes engage themselves in hill rice cultivation, hunting, and gathering of forest products to trade with local communities and earn cash. A very small number of Negrito are still in semi-nomadic where their livelihood is depending on the seasonal forest. Although most of Orang Asli groups are forest dwellers or live in rural areas, a fair number live in or near urban areas where they are involved in waged and salaried jobs (Haron,S. 2008). Due to their heavy reliance on agriculture produce on a small scale, most of Orang Asli are considered as poor and marginal.

Resettlement and redevelopment of Orang Asli have been conducted since the British colonial period due to the communist insurgency threats in the jungle. The early stage involved relocating them away from areas under the Communist influence. In addition, the government felt that Orang Asli communities should not be marginalized from the rapid development experienced by the country. In line with the establishment of Department of Orang Asli (JHEOA) in 1954 under a new law called Aboriginal Peoples Ordinance, the focus of development has shifted to protect Orang Asli and their way of life from the rapid economic development, as well as providing education facilities and suitable development for them. ( Redzuan,M. 2008).

The policy continued after Malaysia gained her independence in 1957. Various transformation programs have been conducted by the government in order to improve the socio-economic status of Orang Asli. These consist of the provision of basic amenities, education, and skills training in cooperation with state governments. Three major development programs were established; structured settlements program, economic development, and social development. (Redzuan, M. 2008).

Structured settlement programs aim to provide better accessibility for the Orang Asli and to improve their socio-economic conditions. The programs can be ex-situ, involving relocating the Orang Asli into a totally new settlement or in-situ, improvement of their existing settlements. Specific programs are Regrouping Plan (RPS), Village Restructuring Project (PSK), New Village Plan (RKB), Natural Disasters Project and Orang Asli Settlement Customary Land Survey (village) / Land Acquisition, all of which provide new or better housing and basic physical amenities such as piped water supply, electricity, roads, and education and health facilities to the Orang Asli communities.

In addition to structured settlement programs, various socio-economic development programs such as entrepreneur mentoring program, retail space development program, income generation program, and Social Welfare Development Scheme (SPKR) have been implemented by the government to enhance the economic status of the Orang Asli. Facilities and programs to improve their health and educations are also part of the whole government efforts.

Many resettlement and redevelopment projects for Orang have been implemented by the government throughout the country over the years. The aim is the same; to provide better accessibility to the community, to improve their access to health and education facilities and services and to improve their socio-economic conditions (Idrus, R. 2011). It is a strategy to integrate them into the mainstream economic development and the wider national community (Abdullah,J. 2016). While the objectives are noble, and some resettled and redeveloped communities have achieved these benefits, certain communities may nor achieved the desired effects. This is perhaps due to unfavorable locations of the new settlements, especially in regards to the traditional source of living from agriculture or jungle produce, to the social and psychological impacts of adapting to a new and modern environment.

The resettlements of Orang Asli have brought mixed results, judging by various studies evaluating their impacts in Malaysia. Lim (1997) cited by Abdulah, J. et.al (2016) argues that regrouping exercise of Jakun families in Keratung and Bulit Seruk 3 was a success due to higher income from permanent agriculture and wage earning. Improved housing and physical facilities, as well as the better confidence of the community, were also evident. This is perhaps due to the facts the Orang Asli volunteered to participate in the regrouping program. A study by Abdullah, J. et al (2016) of Orang Asli Resettlement Project (PROSDET) Pantos in Pahang found only slightly half (50.4 percent) of the Orang Asli resettled were satisfied with their new settlement.

On the other hand, Ab Hadi et. Al (2013) argued that the resettlement of Orang Asli have a negative impact on the environment, negating the aim of conservation initially envisage. Forum Asia contends that it leads to increased poverty and deterioration of health among some villagers. Karim, H. (2012) found that the resettled Orang Asli in urban Bukit Lanjan had difficulties in adapting to new life in metropolitan settings. Abdullah, J. and Borhan, $\mathrm{M}$ (2015) found that almost half of Orang Asli resettled and surveyed in Bukit Lanjan prefer to move out of the new urban settlement despite given comfortable houses. Some of the houses were found to be abandoned.

Resettlement and redevelopment of indigenous people would bring social change to the community. Manciones,J. (1999) cited by Karim, H. (2010) argues that while some societies change faster than the others, hunting and gathering societies change rather slowly. Manciones also offers four dimension of modernity which include decline in social life around family, expansion of 
individualism, increase of social diversity, and the prevalent of future oriented thinking and actions. There are various studies and theories on positive and negative impacts of modernization process, which resettlement and redevelopment are parts of, such as those proposed by Ashraf El Gannam (2001) and Turan \& Besirli (2008).

Thus, there is a need to research further about the impacts of resettlement and redevelopment of Orang Asli in different settings - in situ and ex-situ. This study is one of those research. While previous studies done by the authors in the past were on impacts of resettlement of Orang Asli (ex-situ development), this study focuses on the redevelopment of Orang Asli community on existing site (in-situ) development. Perhaps it may provide different findings compared to other studies and make a worthwhile contribution to the study of Orang Asli redevelopment and resettlement.

\subsection{Methodology}

The main methodology of this study is through a socio-economic and satisfaction survey of all 92 households of the Orang Asli settlement in Ulu Kuang, Selangor. The researchers conducted the survey on three different days with the aim of getting all 92 households to participate. Despite that, only 73 households participated in the survey due to the facts that some were away in the forests or other locations on all three days. In addition, site observations and physical analysis of the settlement were also carried out. The data collected were analyzed using two main techniques, namely descriptive and comparative analyses of their conditions before and after the redevelopment of their settlement. The scopes of analysis are the physical characteristics of the settlement and the socio-economic conditions of the Orang Asli inhabitants. The criteria chosen for the former are provision of housing, commercial and services, infrastructure and utilities, and public facilities. For the socio-economic conditions, the criteria chosen are employment, income and property ownership. These are the criteria which are important towards achieving the main objectives of resettlement and redevelopment of Orang Asli, namely to improve physical and services provisions, and to improve their socio-economic conditions.

The questionnaires of these criteria use the Likert scale of 1 till 5 , with 1 being very unsatisfied and 5 being very satisfied. Respondents were asked of their opinion for condition before redevelopment and after redevelopment of each criterion. The mean of each criterion supported by physical observations are used as the main findings of this study.

\subsection{Study Area}

The study area of this research is located in Gombak district, in the State of Selangor, Malaysia. This Orang Asli settlement is under the administration of Selayang Municipal Council which is an urban local government within Metropolitan Kuala Lumpur. It is about 30 minutes' drive north of the Malaysian capital. The Ulu Kuang Orang Asli settlement was redeveloped on site by the government about a decade ago. The settlement had been gazetted as Orang Asli Reserve by the state government, covering 347 acres. It is occupied by 470 peoples, consisting of 120 families. A total of 75 families are Muslim, 43 families are Temuan and 3 are Christian families (Department of Orang Asli Development - JKOA 2013). However, the survey results later reveal that the demography of respondents slightly different from the statistics given by the JKOA. Figure 1 shows the site plan of the settlement.

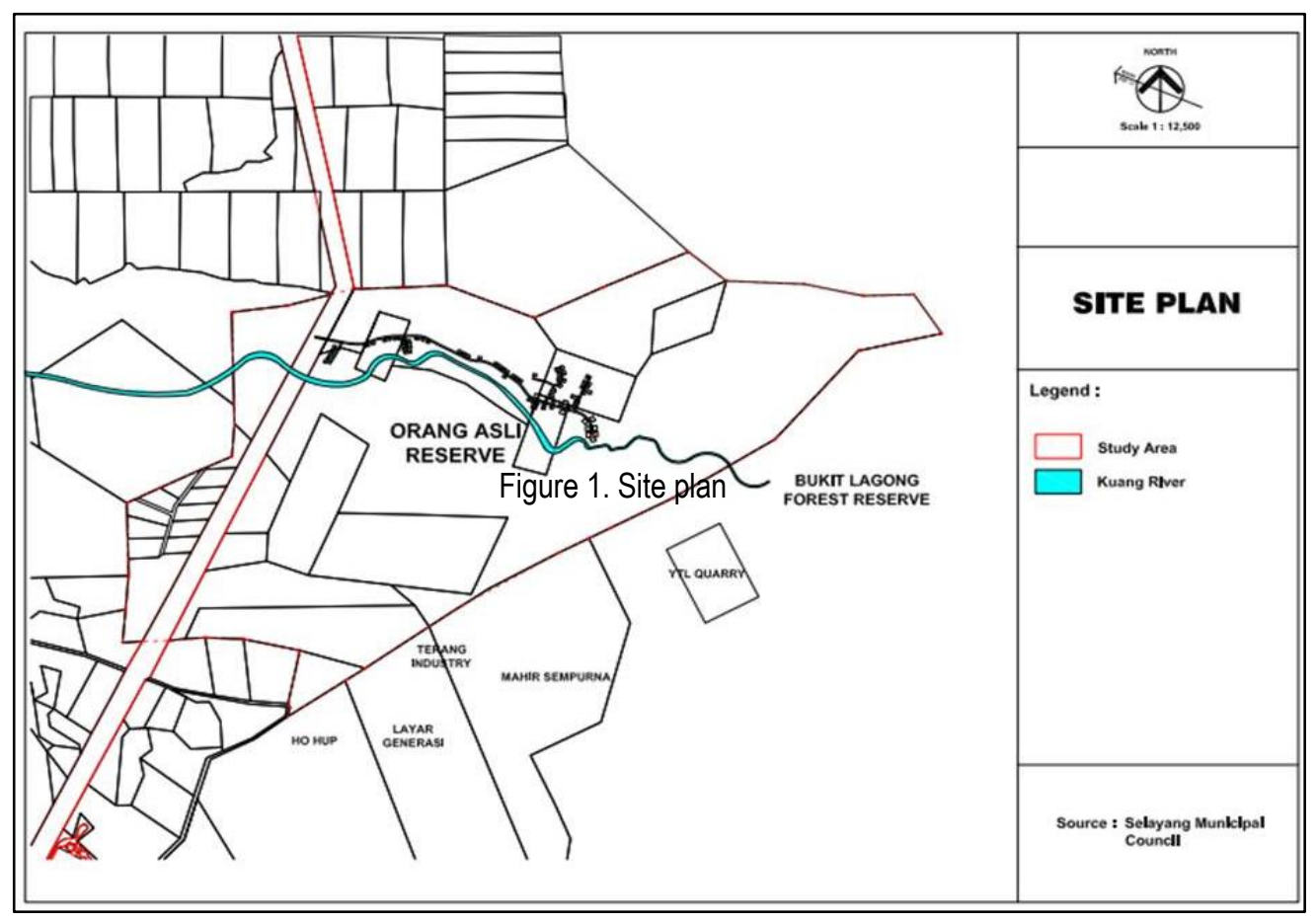




\subsection{Results and Analysis}

The analyses which covered demography and socio-economy of respondents, physical analyses of the settlement and their satisfactions of the settlement are reported below.

\subsection{Respondents' Demographic Structure}

Temuan community is one of the seven tribes in the Malay Proto group. There are about 27,590 Temuan community in Peninsular Malaysia. Compared other Orang Asli communities, The Temuan community settlements are rather small in size and population, with not more than 150 people in each settlement. Table 1 shows that the distribution of the 73 respondents are fairly balanced in terms of gender, with male respondents slightly higher than the female. Each respondent represents his or her household. In terms of age group, a majority are below the age of 44 . More than 9 out 10 respondents identify themselves as Temuan, making the village an overwhelmingly Temuan Orang Asli settlement. Almost 60 percent of respondents practice animism while the second highest group is Muslims.

Table 1. Respondents' age and gender

\begin{tabular}{|c|c|c|c|c|c|c|c|}
\hline \multirow{2}{*}{ Gender } & \multicolumn{7}{|c|}{ Age } \\
\hline & $15-24$ & $25-34$ & $35-44$ & $45-54$ & $>55$ & Total & $\%$ \\
\hline Male & 5 & 9 & 12 & 10 & 2 & 38 & 52.05 \\
\hline Female & 11 & 8 & 8 & 4 & 4 & 35 & 47.95 \\
\hline
\end{tabular}

Table 2. Composition of Ethnic and Religion of Respondents

\begin{tabular}{|c|c|c|c|c|c|}
\hline \multirow{2}{*}{ Ethnic } & \multicolumn{5}{|c|}{ Religion } \\
\hline & Islam & Animism & Christian & Total & $\%$ \\
\hline Malay & 3 & - & - & 3 & 4.11 \\
\hline Temuan & 25 & 42 & - & 67 & 91.78 \\
\hline Senoi & 1 & 1 & - & 2 & 2.74 \\
\hline Iban & - & - & 1 & 1 & 1.37 \\
\hline $\begin{array}{l}\text { Total } \\
\%\end{array}$ & $\begin{array}{c}29 \\
39.73\end{array}$ & $\begin{array}{c}43 \\
58.90\end{array}$ & $\begin{array}{c}1 \\
1.4\end{array}$ & 73 & 100.00 \\
\hline
\end{tabular}

An analysis of education level of all households found that the Temuan Orang Asli education is spread fairly across all categories. As with other Orang Asli, the percentage has tertiary education is very small, less than one percent. The percentage that never went to school at 22 percent is rather high compared to the Malaysian average. When combined with those who completed only primary school, it was found that those who never attended secondary school is half of the total population, a rather alarming statistic, especially since this community live within the Klang Valley, albeit in a rather rural setting. The low education level of Orang Asli communities throughout the nation has been a source of concern to the government.

This low level of education is translated into the income of Orang Asli. Although majority of households have income above RM1000 per month, closer inspection show that most are barely above that threshold level. However, compared to most Orang Asli, these income levels are much higher, perhaps living within the Klang Valley provide those in Kuang with better paid jobs.

Table 3. Highest Education Level of Orang Asli

\begin{tabular}{|c|c|c|c|c|c|c|c|}
\hline \multirow{2}{*}{ Age } & \multicolumn{7}{|c|}{ Highest Education Level } \\
\hline & Primary School & Secondary School & University/ Collage & Never Attend School & Still Schooling & Total & $\%$ \\
\hline$<5$ & - & - & - & - & 1 & 1 & 0.28 \\
\hline $5-14$ & 1 & 1 & - & 1 & 73 & 76 & 21.00 \\
\hline $15-24$ & 40 & 51 & 1 & 6 & 21 & 119 & 32.87 \\
\hline $25-34$ & 30 & 16 & 1 & 20 & 2 & 69 & 19.06 \\
\hline $35-44$ & 19 & 6 & - & 24 & - & 49 & 13.54 \\
\hline $45-54$ & 12 & 3 & - & 14 & - & 29 & 8.01 \\
\hline$>55$ & 2 & 2 & - & 14 & 1 & 19 & 5.25 \\
\hline$\%$ & 28.73 & 21.82 & 0.55 & 21.82 & 27.07 & 362 & 100.00 \\
\hline
\end{tabular}

Table 4. Monthly Income by Household

\begin{tabular}{lcc}
\hline Monthly Income & Numbers of Families & \% \\
\hline $150-299$ & 1 & 1.37 \\
$300-499$ & 5 & 10.96 \\
$500-699$ & 6.85 & 24.65 \\
$700-999$ & 18 & 51 \\
$>1000$ & 73 & 100.00 \\
\hline Total & 76 & \\
\hline
\end{tabular}

\subsection{Comparative Analysis of Physical Development}

The comparative analyses of the community before and after redevelopment are divided into two segments, physical and socioeconomic developments. Respondents were given a 5 point Likert scale, ranging from very unsatisfied (1) to very satisfied (5). Four aspects of housing were asked of the 73 head of households which include housing arrangement, space, comfort and suitability. 
Overall, their satisfactions had increased from unsatisfied (mean of 2.1) to satisfied (3.86). Three of the four aspects of housing showed rather significant increase, especially housing arrangement and interior comfort. This is perhaps due to the arrangement of the new houses follow proper housing layouts and each house from a road, allowing better accessibilities to occupants. In addition, being made of bricks the news houses better protect the occupants from adverse weather conditions and the provision of indoor plumbing provide better comforts to residents. In terms of position of the houses, the general trend is that many residents are unsatisfied, perhaps because they prefer their houses to face certain direction and for the desire to have much larger compounds.

Figures 1 and 2 show the layout of housing arrangement before and after redevelopment. The houses were rebuilt along the main road which was built after the redevelopment, allowing better accessibility especially for the Orang Asli with motor vehicles. There we now other amenities such as commercial, surau, kindergarten and public hall for the whole community, in addition to open space for sports. These are basic physical facilities built by the government for new Orang Asli resettlement and redevelopment.

Table 5. Overall Satisfaction of Housing

\begin{tabular}{|c|c|c|c|}
\hline Aspect & Before Redevelopment & $\begin{array}{c}\text { Mean } \\
\text { After Redevelopment }\end{array}$ & Change in Satisfaction Scale \\
\hline Housing Arrangement & 1.19 & 4.79 & $\begin{array}{l}\text { From Very Unsatisfied } \\
\text { To Almost Very Satisfied }\end{array}$ \\
\hline Home Space For Family Activities & 2.20 & 4.12 & From Unsatisfied To Satisfied \\
\hline Interior Comfort & 1.72 & 4.28 & $\begin{array}{c}\text { From Unsatisfied } \\
\text { To Satisfied Satisfied }\end{array}$ \\
\hline Position And Suitability & 3.27 & 2.26 & Decreased to Unsatisfied \\
\hline Average Mean & 2.10 & 3.86 & From Unsatisfied To Satisfied \\
\hline
\end{tabular}

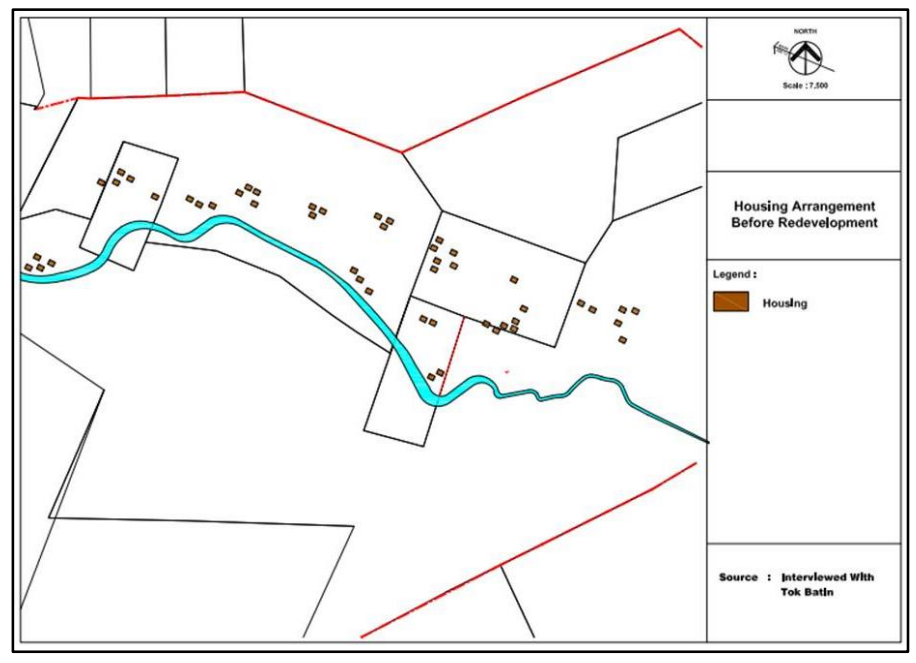

Figure 2: Housing arrangement before redevelopment

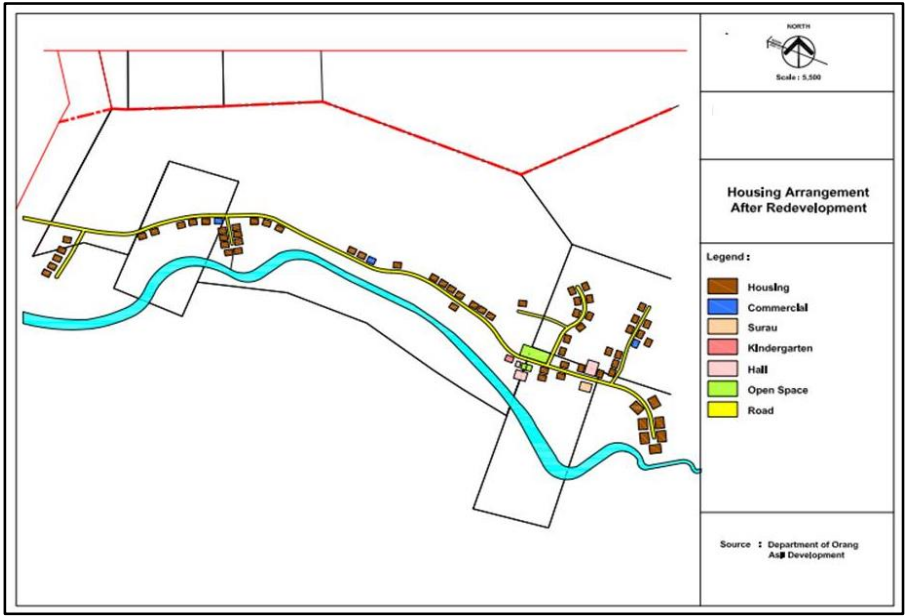

Figure 2. Housing arrangement after redevelopment 
Table 6. Overall Satisfaction of Commercial and Services

\begin{tabular}{|c|c|c|c|}
\hline \multirow{2}{*}{ Aspect } & \multicolumn{2}{|l|}{ Mean } & \multirow[b]{2}{*}{ Change in Satisfaction Scale } \\
\hline & Before Redevelopment & After Redevelopment & \\
\hline Location And Placement Of Commercial & 1.07 & 4.88 & $\begin{array}{l}\text { From Very Unsatisfied } \\
\text { To Very Satisfied }\end{array}$ \\
\hline Accessibility To Market & 1.11 & 4.88 & $\begin{array}{c}\text { From Very Unsatisfied To } \\
\text { Very Satisfied }\end{array}$ \\
\hline Stall/Food Court Facilities & 1.10 & 4.84 & $\begin{array}{l}\text { From Very Unsatisfied } \\
\text { To Very Satisfied }\end{array}$ \\
\hline Average Mean & 1.09 & 4.86 & $\begin{array}{c}\text { From Unsatisfied To } \\
\text { Very Satisfied }\end{array}$ \\
\hline \multicolumn{4}{|c|}{ Table 7. Overall Satisfaction of Infrastructure and Utilities } \\
\hline Aspect & Before Redevelopment & $\begin{array}{c}\text { Mean } \\
\text { After Redevelopment }\end{array}$ & Satisfaction Scale \\
\hline Water Supply & 1.58 & 3.06 & $\begin{array}{l}\text { From Unsatisfied } \\
\text { To Satisfied }\end{array}$ \\
\hline Electric Supply & 1.10 & 4.96 & $\begin{array}{c}\text { From Very Unsatisfied To } \\
\text { Very Satisfied }\end{array}$ \\
\hline Accessibility & 1.10 & 4.97 & $\begin{array}{c}\text { From Very Unsatisfied To Very } \\
\text { Satisfied }\end{array}$ \\
\hline Network Communication & 1.10 & 4.92 & $\begin{array}{c}\text { From Very Unsatisfied To } \\
\text { Very Satisfied }\end{array}$ \\
\hline Provision Of Dumps & 1.00 & 1.30 & No Change \\
\hline Average Mean & 1.18 & 3.85 & $\begin{array}{c}\text { From Very Unsatisfied To } \\
\text { Satisfied } \\
\end{array}$ \\
\hline \multicolumn{4}{|c|}{ Table 8. Overall Satisfaction of Public Facilities } \\
\hline Aspect & Before Redevelopment & $\begin{array}{c}\text { Mean } \\
\text { After Redevelopment }\end{array}$ & Satisfaction Scale \\
\hline $\begin{array}{l}\text { Provisions Of Recreation } \\
\text { And Leisure Area }\end{array}$ & 1.30 & 4.78 & $\begin{array}{l}\text { From Very Unsatisfied } \\
\text { To Very Satisfied }\end{array}$ \\
\hline Education Facilities & 1.12 & 4.95 & $\begin{array}{c}\text { From Very Unsatisfied To } \\
\text { Very Satisfied }\end{array}$ \\
\hline Religious Facilities & 1.12 & 4.95 & $\begin{array}{c}\text { From Very Unsatisfied To } \\
\text { Very Satisfied }\end{array}$ \\
\hline Security Facilities & 1.21 & 4.74 & $\begin{array}{c}\text { From Very Unsatisfied To } \\
\text { Very Satisfied }\end{array}$ \\
\hline Health Facilities & 1.10 & 4.87 & $\begin{array}{l}\text { From Unsatisfied To } \\
\text { Almost Very Satisfied }\end{array}$ \\
\hline Public Transport & 1.12 & 4.87 & $\begin{array}{c}\text { From Very Unsatisfied To } \\
\text { Very Satisfied }\end{array}$ \\
\hline Average Mean & 1.16 & 4.86 & $\begin{array}{l}\text { From Very Unsatisfied To } \\
\text { Almost Satisfied }\end{array}$ \\
\hline
\end{tabular}

Table 6, 7 and 8 are results of the survey related to the commercial areas, infrastructure and utilities as well as the public facilities in the redeveloped community. Overall, for all three components, the respondents indicated that their satisfactions have increased from very unsatisfied (slightly above 1 in the Likert scale) to very satisfied (almost 5 on the Likert scale). For commercial development (Table 6), this was due to the non-existence of commercial are before the redevelopment.

In terms of infrastructure and utilities (table 7), the provision of electricity supply, road and communication networks have improved the comfort of the community tremendously. These were infrastructure that were not available before the redevelopment. However, it was found that the respondents were not happy with the lack of provisions of dumps area which is still not provided. The area is not served by waste collection services due to its rather remote location

The provision of public facilities (Table 8) have improved the respondent's satisfactions tremendously. These are reflected in the very satisfied score for recreation, education, religious, security, health and public transport facilities. This is expected since these provisions were not found in the settlement before its redevelopment.

5.3 Comparative Analysis of Socio-Economic Condition

In addition to physical improvements, the redevelopment has affected the socio-economic conditions of the inhabitants. It was found in all three aspects of socio-economic conditions, respondents indicated that they are currently very satisfied, compared to a very unsatisfied before the redevelopment. These include employment opportunities, income and property ownership. The greater accessibility allows them to go to work in the nearby urban centers which provide better income compared to earlier situation. In addition, since the houses were provided to them by the government, they are very satisfied in terms of property ownership. 
Table 9. Overall Satisfaction of Socio-Economic

\begin{tabular}{cccc}
\hline Aspect & Before Redevelopment & Mean & After Redevelopment \\
Employment & 1.14 & 4.88 & $\begin{array}{c}\text { From Very Unsatisfied } \\
\text { To Very Satisfied }\end{array}$ \\
Fonthly Income & 1.11 & 4.88 & $\begin{array}{c}\text { From Very Unsatisfied To } \\
\text { Very Satisfied }\end{array}$ \\
Property Ownership & 1.06 & 4.97 & From Very Unsatisfied To \\
Very Satisfied & 4.91 & From Very Unsatisfied To \\
Very Satisfied
\end{tabular}

\subsection{Overall Findings and Recommendations}

The survey covered five main components related to the Orang Asli community. The overall score indicates that on average the Orang Asli satisfaction has changed from very unsatisfied to very satisfied. These are especially for commercial and services, infrastructure and utilities, public facilities and socio-economic development. For housing, there was also a rather significant improvement, although not as drastic as the other four categories.

It seems that compared to other Orang Asli communities especially those in very rural areas, The Orang Asli of Ulu Kuang seems to have embraced the improvements to their community much more positively. There are a few reasons for this. The first is that the redevelopment is done in-situ, reducing the negative impacts of resettlement which happened to many resettled communities. Thus, the Ulu Kuang Orang Asli did not encounter disruptions to their daily lives. In terms of physical development, the new provisions of housing, commercial and public facilities have met their expectations of modern environment. Improved accessibility has also made it easier for them to participate in socio-economic activities within the area. The Orang Asli now find it easier to go to their work places and to earn a better living.

Table 10. Biggest Changes of Redevelopment

\begin{tabular}{|c|c|c|c|}
\hline Aspect & Before Redevelopment & $\begin{array}{c}\text { Mean } \\
\text { After Redevelopment }\end{array}$ & Satisfaction Scale \\
\hline Housing & 2.10 & 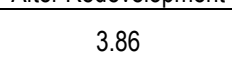 & $\begin{array}{l}\text { From Unsatisfied } \\
\text { To Satisfied }\end{array}$ \\
\hline Commercial And Services & 1.09 & 4.86 & $\begin{array}{c}\text { From Very Unsatisfied To } \\
\text { Very Satisfied }\end{array}$ \\
\hline Infrastructure And Utilities & 1.18 & 3.85 & $\begin{array}{c}\text { From very Unsatisfied To } \\
\text { Satisfied }\end{array}$ \\
\hline $\begin{array}{l}\text { Public Facilities } \\
\text { Socio-Economy }\end{array}$ & $\begin{array}{l}1.16 \\
1.10\end{array}$ & $\begin{array}{l}4.86 \\
4.91\end{array}$ & $\begin{array}{l}\text { Very Unsatisfied To Very Satisfied } \\
\text { From Very Unsatisfied To Very Satisfied }\end{array}$ \\
\hline Average Mean & 1.16 & 4.86 & From Very Unsatisfied To Very Satisfied \\
\hline
\end{tabular}

Despite these improvements, there are still rooms for further improvements. These include provision of reliable water supply and solid waste disposal system. These are the two main factors which were found to be in need of solutions.

In terms of socio-economic development, there should be some programs to empower themselves to improve their socio-economic status. These include skill training courses and other educational courses since many of the Orang Asli have low education levels. Being close to major urban centers the Orang Asli would have great employment opportunities if they are skilled and ready for the modern workforce.

\subsection{Conclusion}

The paper has highlighted the positive impacts of the redevelopment of Orang Asli settlement in Ulu Kuang, Selangor. It was found that in-situ development which provides basic physical and infrastructure facilities have improved the Orang Asli communities. This is rather different compared to resettlements programs of Orang Asli in other areas. Perhaps this is due to the fact that these Orang Asli were not moved to new locations, thus providing continuity in their life. The fact that the land has been gazetted as Orang Asli Reserve played a big role in their success. In addition, being in the Klang Valley, near main employment centers have helped their socioeconomic conditions as well.

The study has confirmed existing literature that for indigenous people to adapt to the modern environment, in-situ development is perhaps is the better option than ex-situ resettlement. The sense of community and security that have been improved are likely to make them feel better and more satisfied. In addition, a better physical environment which makes it easier for them to earn a better living, especially through improved accessibility to employment opportunities, are crucial for the success of redevelopment or resettlement programs. Physical development together with improved socio-economic development would significantly improve the living condition and quality of life of this marginalized community.

\section{References}

Ab.Hadi, M. Y., Roddin, R., Razzaq, A. R. A., Mustafa, M. Z., \& Baser, J. A. (2013). Poverty Eradication through Vocational Education (Tourism) among Indigenous People Communities in Malaysia: Pro-poor Tourism Approach (PPT). Procedia - Social and Behavioral Sciences, 93, 1840-1844. doi:10.1016/j.sbspro.2013.10.127 
Abdullah, J., Ahmad, C. B., Sa'ad, S. R. M., \& Wahab, S. S. (2015). Public Participation in the Kuala Lumpur Draft City Plan 2020. Procedia - Social and Behavioral Sciences, 168, 70-75. doi:10.1016/j.sbspro.2014.10.211

Abdullah, J., Borhan, M. A.-A., \& Ahmad, C. B. (2015). Orang Asli Resettlement in Urban Environment at Bukit Lanjan, Selangor, Malaysia. Procedia - Social and Behavioral Sciences, 201(February), 71-79. doi:10.1016/j.sbspro.2015.08.132

Abdullah, J., Sayuti, N. M., Arshad, A. A. M., \& Embong, M. R. (2016). Living Conditions in Orang Asli Resettlement Project (PROSDET) of Pantos, Pahang, Malaysia. Procedia - Social and Behavioral Sciences, 222, 143-150. doi:10.1016/j.sbspro.2016.05.204

Ashraf Ragab El-Ghannam (2001). Modernization in Arab Societies: The Theoretical and Analytical View, International Journal of Sociology and Social Policy, 21(1), $99-131$

Haron,S.. Nordin, M., Wahab, R and Hayati, F (2009). Lifelong Learning Among the Malaysian Orang Asli Bateq Community. UiTM Shah Alam.

Idrus, R. (2011). The discourse of protection and the Orang Asli of Peninsular Malaysia, Akademika 35 (Julai 1989) 75-86.

JAKOA. Laman Web Rasmi Jabatan Kemajuan Orang Asli. Kementerian Kemajuan Luar Bandar dan Wilayah. http://www.jakoa.gov.my/web/guest/9

Karim, H. A., \& Hashim, A. H. (2012). The Effect of a Resettlement Scheme on the Social-Cultural Changes of the Temuan Community. Procedia - Social and Behavioral Sciences, 42, 362-373. doi:10.1016/j.sbspro.2012.04.200

Manciones, J. (1999). Sociology, $7^{\text {th }}$ Edition. Ner Jersey: Prentice Hall.

Nicholas, C. (2000). The Orang Asli and The Contest For Resources : Indigenous Politics, Development and Identity in Peninsular Malaysia. Kuala Lumpur. Vinlin Press Sdn. Bhd

Redzuan,M. (2008). Isu, Transformasi dan Cabaran. Universiti Putra Malaysia

Suki Mee (2009). Orang Asli Perak : Perayaan Jis Paid an Adat Perkahwinan. YOAP BHD.

Turan, M.T \& Besirli, A (2008). Impact of Urbanization Process on Mental health. Anatolian Journal of Psychiatry. 9: 238-243. 